\title{
A obra poética de Rafa Yáñez
}

\author{
The Poetic Work of Rafa Yáñez
}

\author{
JUAN A. RODRÍGUEZ García \\ Universidad Nacional de Educación a Distancia \\ juanrogar@hotmail.com \\ Recibido: abril 2016. Aceptado: mayo 2016
}

\begin{abstract}
Resumo: Estúdase e caracterízase a obra poética de Rafa Yáñez, membro do Grupo Bilbao, como poeta da súa xeración e nos aspectos correspondentes a unha literatura ectópica ou transterrada nunha situación de contacto lingüístico, por ser escritor de lingua galega en Madrid. Como poeta do seu tempo, mostra temas e formas propios da poesía posmoderna, especialmente unha poesía da experiencia, aínda que trata tamén outros temas, sobre todo sociais. Como poeta transterrado, mostra unha certa hibridación cultural: non esquece as súas raíces galegas, pero incorpora tamén trazos urbanos do seu contorno actual nunha gran cidade como Madrid.
\end{abstract}

Palabras clave: Bilingüismo literario, Grupo Bilbao, literatura ectópica, literatura intercultural, Rafa Yáñez.

\begin{abstract}
On this paper we will study and feature the literary work of Rafa Yáñez, a member of the so-called Grupo Bilbao, as a poet of his generation and as an example of ectopic literature, that is to say, the literature written in a language other than the one proper of a given territory, in a situation of language contact. As a poet of his times, he develops typical postmodern subjects and manners, in particular an experience poetry, though considering other topics such as social ones. As an emigrated poet, he shows a certain degree of cultural blend: he never reject his Galician origins, and at the same time he integrates several urban characteristics from his present residence land in such a large city like Madrid.
\end{abstract}

Keywords: Ectopic literature, intercultural literature, Grupo Bilbao, literary bilingualism, Rafa Yáñez.

\section{INTRODUCIÓN}

O poeta Rafa Yáñez naceu en Vilalba (Lugo) en 1979, aínda que de pais non galegos. Trasladouse a Madrid para os seus estudos universitarios de Comuni- 
cación Audiovisual, e na capital contactou co Grupo Bilbao (GB), do que forma parte case desde os seus inicios en 1996, co que ten desenvolvido a súa traxectoria como escritor, e ao que se vencellou dende o Departamento de Filoloxía Románica da Universidade Complutense de Madrid, como outros varios autores novos membros dese mesmo Departamento (Acuña 2012: 263; Luna 2012: 32). É tamén un activo participante da actividade editorial común do grupo.

A obra poética de Yáñez consta basicamente de cinco poemarios: Onte chovía (2000), Lembranzas e olvidos dun estraño (2001), Da chá ao lonxe (2011), Axóuxeres da melancolía (2013) e Farewell (2014a), amais dalgúns poemas soltos en obras colectivas (Muller de doce sal, 2000; Marés nos pousos de café, 2010; Bilbao: Antología de poesía gallega en Madrid, 2012; Esferografías, 2014; Fisterras, 2015), e localizamos dous relatos curtos: un sen título no libro colectivo do GB Hipnotopia en doses pequenas (2013) e o outro titulado Epílogo (Yáñez 2014b: 239-240), no número 17 da revista Madrygal.

Podemos ver, por tanto, que é un poeta novo aínda que consagrado por unha obra moderadamente extensa. Porén, aínda non foi obxecto de ningún estudo específico. Ademais, como veremos, resulta bastante representativo de moitos dos trazos máis comúns entre os integrantes do GB.

Por todo o anterior, formulamos como obxectivo fundamental deste estudo a análise e caracterización da obra de Rafa Yáñez, de cada un dos seus cinco poemarios individualmente e no seu contexto, de modo singular e máis encadrado na literatura actual, con fincapé tamén nos seus trazos ectópicos (literatura de fronteira ou trasterrada) no sentido de Albaladejo (2011: 153), e o seu carácter bilingüe. Amais do estudo directo da súa obra, foi moi útil para o seu desenvolvemento a comunicación mantida co autor, quen respondeu a todas as cuestións que lle formulamos.

\section{ANÁLISE DA SÚA OBRA}

\subsection{Onte chovía (2000)}

Foi editado pola Asociación Celso Emilio Ferreiro na colección O Roibén. A súa estrutura consta dunha introdución con tres poemas, nomeados coas letras A, B e C; un corpo principal de vinte e oito poemas con números correlativos; e un epílogo con outros tres poemas, X, Y, Z. Todos levan un título final, como conclusión, «Reflexos de...» e fan referencia a un elemento ou recordo concreto evocado e que dá lugar ao poema: Reflexos humanos, dun camiño, do tempo, dun segredo, do mar...

No seu limiar, Blanco (2000: 3) fala de «unha metáfora impresionista vestida de sensacións». É efectivamente unha poesía de imaxes, de sentidos e de sentimentos. Alén diso, engade certeiramente que carecen de materialismo ou racionalismo. Na súa análise, Luna (2010: 95; 2012: 191-195) subliña que é unha poesía de la experiencia, aínda que o asocia ao sentimento de «saudade», ao desarraigamento de quen abandonou a súa Galicia natal para se instalar na 
grande urbe. Porén, percibimos pola nosa banda un conxunto de poemas, pola contra, froito de formulacións moito máis reflexivas e asisadas.

Comeza expondo unha certa idea do iniciático, dos temores que supón botar a andar por novos camiños, sobre todo nos poemas B e C iniciais. A este inicio do «camiño» fai referencia tamén o poema 6 , unha sorte de descuberta da realidade cegadora, un comezo doloroso que trae certos ecos do mito platónico da caverna.

Pero o motivo máis repetido ao longo das composicións, e seica impropio nun poeta que daquela contaba apenas vinte e un anos, é o do tempus fugit, o do envellecemento, por exemplo nos poemas 2 («Véxoo, está próximo. / Afástase: non o lembro»), 3 e 4 . Algún, como o 13, está ambientado incluso co tópico barroco das ruínas:

\section{Tras o arco derruído \\ proliferan as metamorfoses \\ de almas cansinas \\ que desexan esquecer \\ unha antiga metáfora \\ que as ten aferradas.}

Similar ao tópico das ruínas é o motivo desenvolvido no poema 7 , onde parece imaxinar noutro tempo o que é agora un lugar pacífico, tranquilo, cotián, pero onde se produciran noutrora mortes entre ruídos enxordecedores, quizá a evocar o que puido ser un campo de batalla, presentado dende un punto de vista tráxico e de ningún modo épico.

Hai tamén ecos do Barroco ou do Romanticismo co poeta morto do poema 17, quen se revolve dende o outro mundo por sentirse mal interpretado e para procurar o que, pensa, debeu ser o seu destino. Que se trata dun poeta antigo, clásico, ponse de manifesto tamén na propia construción do poema, estraña en Yáñez, xa que presenta frecuentes rimas en asonante e unha certa isometría nos versos.

En moitos poemas, os seus protagonistas fan balance das súas vidas. No 14 presenta un ancián que vive para esquecer, e no 21 quen agarda xa un xequemate, «Aquel inminente futuro» de quen ve claramente o seu final como unha labazada de realidade. Realidade á que, porén, non quere volver o protagonista do 5, quen se sente mellor no seu propio mundo, «naquel curruncho». No 23 fai un repaso do vivido; iso conta mentres experimenta o seu propio velorio nunha imaxe moi conseguida polo autor. Contrario é o que expresa o protagonista do poema 27 , facendo tamén un rápido repaso a unha vida chea de pesimismo, dúbidas e procura inútil da coherencia, para concluír sen saber se pagou a pena vivir ou se o que veña será mellor ou peor.

Nos derradeiros poemas do libro déixase levar mesmo por certo existencialismo e a formulación do sentido da vida: a falsidade vital no poema 27; ou a vida como ir morrendo, no 28 . No antepenúltimo poema («X») parece identificar a vida como un camiño que se vai percorrendo (motivo tamén intuído nos 
poemas iniciais da obra), e no que imos atopando diferentes elementos, fitos que nos van indicando o rumbo que debemos seguir:

\author{
Admiro as luces \\ que a dereita e esquerda \\ marcan o meu camiño. \\ (...) \\ Recorrentes son \\ os teus acenos \\ e as túas luces, \\ os meus cantos \\ e a verdade.
}

Son varios os poemas que tratan o tópico do paraíso perdido. Fase de melancolía quizais por un amor que marchou, e que presenta vivida de varias maneiras: coa esperanza ilusoria no 8, onde o amante, cara ao mar, aínda pensa: «voltará, de seguro que voltará». Co conformismo fatalista do 10 «Sabía que tiña que ser así». Cun conformismo máis optimista no 18, ao persuadirse de mirar adiante. Aceptando deportivamente o ocorrido no 15, se é o que a outra persoa desexa para ser feliz. E unha perda dolorosa vívese no 12, coa bágoa que vai esvarando pola meixela, froito do desespero.

No poema 20 describe un ciclo das fases do namoramento, identificadas coas estacións do ano: a paixón na primavera, a paz no verán, a excesiva paz no outono e así ata que o inverno remata no alcohol. Este motivo do amor como un ciclo anual verase repetido na súa obra futura.

A paisaxe urbana está presente no poema 22, para negar o tópico da soidade que se sente no medio da multitude anónima; ou, polo menos, é un sentimento que xa superou: «Onte chovía. / Hoxe, vai sol». Pasear, ruar, tranquilízao, como nos advertiu tamén no poema 9 , onde a escuridade das rúas coñecidas é vivida coma un refuxio. Fronte a iso, o anódino dunha vida tranquila e de coleccionismo de anacos de papel pode acompañar paradoxalmente unha vida intensa, como conta no 24 .

Aínda que son varios os poemas que seguen unha estrutura con presentación, nó e desenlace, só o 16 é propiamente narrativo. Fálanos do esplendor e a caída dun caudillo guerreiro imaxinario, o Ruphrakán de Saulzdraka, que creou Yáñez a partir das súas lecturas sobre a Rota da Seda.

A parte máis irracional do poemario está representada quizais polo poema 19 («Reflexos dun soño»), cheo de imaxes e vivencias oníricas; e o 25 («Reflexos dunha loucura I»), composto por unha sucesión de ideas aparentemente inconexas, que evocan ese estado de loucura do que nos fala o seu título. Recolle ademais unha das poucas escatoloxías do autor, que nos pode recordar por exemplo ao seu admirado Leopoldo María Panero:

Mentres a auga corre, moi rápido, el aliviará as súas entrañas. 
O poemario fecha cun par de composicións metapoéticas, sobre o proceso creativo. $\mathrm{O}$ «Y», dun ton moi narrativo, sobre o tema da inspiración como elemento necesario á hora de compoñer. Ao respecto, cóntanos o propio Rafa Yáñez: «Normalmente es mucho de inspiración, aunque cada vez tiro más de oficio. Sobre todo en épocas de poca producción ${ }^{1} »$. Finalmente, no «Z» cóntanos para que escribe: para dar a súa visión das cousas e para sosegar insatisfaccións.

En conxunto, podemos falar dun poemario reflexivo: en boa medida son uns exames de conciencia ante o vivido e unha procura do sentido da vida; diferentes actitudes fronte ás rupturas amorosas e fronte ao proceso creativo.

\subsection{Lembranzas e olvidos dun estraño (2001)}

Prologado por Vicente Araguas e editado tamén na colección $O$ Roibén pola ACEF. Consta de tres partes, cos títulos de «Ruta ociosa», «Toxicomanía púrpura» e «Lembranzas», cada unha delas composta por diversos poemas, ben con título propio ou ben numerados en romanos.

Segundo Luna (2012: 195-199), a primeira parte é unha viaxe iniciática, a segunda céntrase no erótico e a terceira incide na ausencia. Porén, nós consideramos «Ruta ociosa» como un canto ao fastío vital: do tempo presente, da cidade na que se vive e da soidade, ata a caída no estoicismo. As outras dúas partes centraríanse no tópico do paraíso perdido, a nostalxia do amor que marchou, tema común tamén no seu primeiro poemario (Onte chovía).

«Ruta ociosa» está formada por un conxunto de poemas de desilusión, de farta, do afogamento en alcohol ante a falta de expectativas. Comeza con «Mar 'abtudo'», que cun ton de prosa poética mostra a Corto Maltés aburrido de tanta bohemia e aventura constante. Outros dous poemas, "Viaxeiro» e «XII», insisten nestes ambientes das tabernas do porto, do alcohol e a actitude de carpe diem nihilista ante a imposibilidade de cambiar o mundo. Aínda así, en «Medo», moi narrativo e prosaico fronte á linguaxe xeral vangardista, a conciencia xéralle insomnio e impídelle gozar.

No poema «X» volve á reflexión sobre a creación poética, para describir o oficio de escritor como o do inventor dunhas realidades alternativas que seica o axudan a soportar todo ese pesimismo antes exposto.

Finalmente, esta parte pecha con cinco series de versos, numeradas en romanos I, II, III, IV e V, onde describe, apostrofando, unha paisaxe viva, unha parte da súa historia persoal, na que se recoñece unha evolución (igual que nas actitudes humanas) segundo a época do ano na que se encontre, aínda que conservando certo carácter constante. Trátase así dun poema cíclico, estrutura utilizada con frecuencia por Yáñez.

\footnotetext{
${ }^{1}$ Correspondencia persoal co autor.
} 
«Toxicomanía púrpura» entra de pleno no amor ausente. Divídese en tres partes: «Eu», onde, de novo coa lúa como testemuña e cun detalle escatolóxico («mentres mexo baixo un carballo»), bota de menos a quen, en ocasións, botou de máis; «Ti», a impotencia de ser o amante e non o amado, aínda que acepta con resignación a circunstancia; e «Nolos dous», a lembranza amarga das noites cheas de erotismo ante unha situación que non acaba de asumir:

Imaxino que es miña

cando en realidade,

es de outro.

Até que se dá conta de que a solución está nas súas mans:

Despedila

con branco pano,

só depende de min.

En «Lembranzas», a última parte do poemario, os recordos da ausencia abandonan o erótico para centrarse máis ben no cotián e no proceso de ruptura amorosa, na necesidade de saír dese pensamento recorrente. Destaca aquí a abundancia de imaxes sensitivas: a amargura, morno, húmido... Sentidos moitas veces desarranxados, co frío que cheira e se pode contemplar, o silencio vertical do ambiente, un olvido verde... algo así como os sentidos múltiples dos que fala Saldaña (2009: 164), recurso moi explorado na poesía posmoderna.

No derradeiro poema, «Segunda lembranza», asocia de novo as diferentes etapas dunha historia de amor coas estacións do ano, segundo os tópicos máis clásicos: o renacer da primavera, a pasión e o desexo do verán, a saudade do outono e a morte final no inverno.

Poemario, en definitiva, cheo de lembranzas inútiles e dolorosas, e co desexo duns olvidos necesarios que non chegan. De feito, remata con «lémbrote...», con puntos suspensivos a modo dun eco, como un final falso, aberto.

\subsection{Da Chá ao lonxe (2011)}

Aparece dez anos despois do anterior poemario, período que coincide cun lapso de relativa inactividade do Grupo Bilbao e no que as publicacións de Yáñez limítanse a colaboracións en libros colectivos. Como el mesmo declarou:

Non teño présa por publicar, da poesía non se vive (...) é un poemario que escribín entre 2005 e 2009. Tiña escrito iso aí, esperando unha oportunidade que xurdiu por petición do Instituto de Estudos Chairegos (...) Trata da evolución, da aprendizaxe ó crecer, fanse referencias ó tempo, a crecer, a levantar a cabeza contra os golpes da vida².

2 Diario El Progreso (Vilalba), 7 de xuño de 2011. 
É sen dúbida o poemario máis propio dun escritor trasterrado de todos os seus, pois está dedicado integramente á súa terra natal, a da nenez,

Cheo de morriña, como se fose deseñado polos ollos de neno que xa non teño aderezado coa visión crítica de adulto. Nel xúntanse a impotencia ante os feitos da vida co optimismo de ter que vivila e saber que hai un lugar onde xa se foi feliz ${ }^{3}$.

Previamente, o libro foi reseñado por Mera (2012) e Luna (2012: 200). Abre cunha cita de Pessoa, á que segue un poema introdutivo sen título, ambos unha declaración de intencións e unha actitude ante a obra; no poema dinos:

\section{para voltar á Chá \\ non preciso luvas \\ na Chá comezou todo}

A continuación, co título común de «Recitativo», ven o corpo do poemario, outras dezanove composicións, todas agás unha sen título e sen case signos de puntuación nin maiúsculas que indiquen principios nin finais, o que dá a sensación duns textos fragmentarios (Saldaña, 2009: 225), como fragmentarias poden ser as lembranzas que deran lugar aos propios poemas. Recurso utilizado por Yáñez en toda a súa obra, aínda que aquí ponse de manifesto seica con especial frecuencia. Por iso, para a súa cita, usaremos o número de orde na obra e o primeiro verso de cada poema a modo de título.

Entre os temas tratados predomina sobre todo a nostalxia, a morriña dunha terra e da súa nenez alí vivida.

As paisaxes son moi abundantes, e están descritas con figuras marcadamente pictóricas que nos remiten ao romanticismo de Friedrich e ao impresionismo alemán. É o caso do 5 («vixía das luciñas») ou o 13 («Reintégrase o día no ano»), dedicado ao pintor gaditano e chariego de adopción José Enrique Chanot e con senso meta-artístico. O conxunto da comarca, a modo de microcosmos, está descrito no 19 («No alto de Monselván»).

O impresionismo alemán é mencionado expresamente no 17 («A Chá ten sabor»), no que, con aire de lema turístico, mostra a zona mediante os cinco sensos nunha mestura de poesía, pintura e incluso cinema e danza, que leva a cabo tamén no 8 («súmome»).

Paisaxes impresionistas, aínda que co mar como motivo, aparecen igualmente noutros dous: o 14 («a orquestra a carón do templete»), cheo de imaxes de natureza; e o 16 («Se algún tempo foi mar sen melodía»), co mar como lugar mitolóxico onde a melancolía faise presente a través dun fado.

A sempiterna choiva galega aparece no 15 («Ouvea un can») e no 9 («a luz sabática reflectida»).

\footnotetext{
3 Diario A voz de Vilalba, 30 de maio de 2011.
} 
Destaca tamén a intertextualidade no 12 («Hai un paraíso»), onde compara a Terra Chá co País das Marabillas de Lewis Carrol, nunha volta á súa nenez.

Esta volta á infancia é o outro grande asunto do poemario; lembranzas nostálxicas de cando a Chá parecía englobar todo o mundo existente. Nostalxia non só polo vivido senón tamén por crecer sen ter gozado da evolución, por exemplo no 3 («Cando o Trimaz e o Madalena»). O paso do tempo aparece tamén no 18 ( «Cando as cinzas dunha lumeira»), onde parece identificalo co soprido do vento, fronte ao estático e invariable das pedras e da propia Terra Chá.

As viaxes á terra dende Madrid, xa de adulto, descríbense no 6 («Coma no poema de Luz Pozo»), enumeración de lugares chairegos, igual có 11 («A cotío cumpro»). Do mesmo argumento trata o 10 («Sóubente outono derradeiro»), onde a Chá asóciase a un bo e vello amigo.

Contén ademais unha elexía funeraria no 4, «A D. Xosé Fariña Jamardo», escritor galego que estivo vinculado nos seus últimos anos ao GB. Son frecuentes en xeral as citas ou mencións a outros poetas, sobre todo galegos, como Manuel Pereira, Luz Pozo ou María Mariño; e ao chileno Neruda.

Un pensamento solto, case coma un haiku, é o poema 7 («a soidade»), reflexión sobre a soidade e o silencio.

Trátase en definitiva dun ollar melancólico a unha parte importante da súa vida, a infancia e a adolescencia, pero sen caer na idealización extrema. Como el mesmo comentou, "Yo siento que fui joven en Madrid más que allí» ${ }^{4}$. Segue ademais unha estrutura cíclica, onde a Chá é o punto de partida; e, como di no derradeiro verso do libro, «na Terra Chá rematará todo».

\subsection{Axóuxeres da melancolía (2013)}

O cuarto poemario de Rafa Yáñez supón, máis que nada, unha continuación dos temas que xa viñera tratando nos anteriores: o paso do tempo, as paisaxes, a metapoesía e, ante todo, unha chamada xeral ás lembranzas da vida, ao que bota de menos, dende un ton xeral de saudade. Resultan senlleiros os moitos poemas dedicados a amigos; e, como importante novidade, a introdución de temas sociais. Como o propio autor describe en prosa poética no limiar da obra:

Sinto que cómpre facer ruxir os axóuxeres que me trouxeron até eiquí e facelos soar para que nunca deixen de se sentir.

Somos o que vivimos, en pasado, no presente e no futuro.

Compoñen a obra 38 poemas, en xeral curtos, divididos en cinco partes encabezadas por breves composicións que anticipan o contido de cada unha delas. Uns poemas están numerados en romanos; outros levan un título curto que fai referencia á persoa ou ao lugar ao que van dedicados. Comeza ademais

\footnotetext{
${ }^{4}$ Correspondencia persoal co autor.
} 
o poemario cunha cita de Thomas Hardy, escritor inglés caracterizado polo seu pesimismo e o seu fatalismo, rasgos que con frecuencia tinguen o conxunto desta obra.

O poema que abre a primeira parte resulta unha declaración de intencións:

de súpeto espertei

(...)

cos meus soños anestesiados

Seguido de dúas composicións (I e II) que nos falan do acto de escribir e do seu obxectivo; como di en «II»:

ás veces esquecer é unha solución

eu

son incapaz

Temas que marcaban boa parte do seu primeiro poemario volven a aflorar aquí: o tempus fugit en «III», o carpe diem e os propósitos de emenda en «Aninovo na illa ou agardando na Valetta»; o tedio vital, a soidade e a ameaza do mundo exterior (o vento da rúa) en «VII».

As paisaxes aparecen en «16 de febreiro de 2012», onde colide que nunha zona de montaña haxa uns mozos cantando música brasileira; composición que fala de música e que é ao mesmo tempo moi musical, case lista para ser rapea$d a$ con esa anáfora de «por que?» coma un refrán repetitivo e uns versos de métrica máis ou menos homoxénea que contribúen a dar un aire de diálogo cantado. En «V» lévanos polos recordos dunha viaxe pola Europa Central.

En outros dous comeza cunha paisaxe para rematar no social, coma se despois de evadirse nunha descrición poética vóltase de súpeto á realidade: en «IV», onde o temporal supón perdas para a frota amarrada; e «Dende illa Pancha», onde un sensitivo paseo pola praia acaba nunha volta á realidade na secuencia final de versos:

\section{auga batendo conciencias \\ ESPERTA! \\ sociedade civil}

Temas máis puramente sociais aparecen en «IX», unha chamada á loita e unha causa persoal: «non rindo as súas mamandurrias». E a autocrítica de non darse conta no seu momento, de mozos, dalgunhas cousas, en «XI», polo que están «obrigados a repetir a historia». A paternidade é un tema tamén novo, e se fai presente na escena de berce do «VI».

A segunda parte, «a vida escúlpeme / con bicos de morte», é a máis dura, con temas sociais como as difíciles condicións laborais do campo en «A neve e o sacho» e «Eu tamén tiven avós», de aire costumista; a loita proletaria en «VI», 
coas protestas dos obreiros de Bazán en Cádiz; ou a fantasía fronte á realidade en «Cinema», cando á saída do cinema atópase cun accidente de tráfico con mortos.

Tamén hai elexías funerarias, a personaxes anónimos en «O rostro de Cándido» e «IX»; e a Martín Seco Cendrán, dirixente político galego, en «Ao Cid da Chá». Ao respecto, dinos o autor:

Hay de todo, gente anónima o gente de la tierra, alguno famoso (muy admirado por mí) no lleva nombre porque sé que le gustaría asís.

A terceira parte, «non vos vexo, non / mais sempre aí sempre», compona tres retratos de persoas referidas polo seu nome propio: «Mati», unha figura de muller; «Ernesto», un pianista e as súas mans; «Ana», xogo metalingüístico e ortográfico para xogar co palíndromo.

«Novos axóuxeres» é a cuarta parte, dedicada ás acordanzas de persoas, neste caso vivas. Unha («Café no Lucky») está encadrada nunha estadía en Irlanda; os demais son evocacións centradas na propia relación con quen é obxecto do poema. A maioría van dirixidos a compañeiros do Grupo Bilbao (Carmen Blanco, Vicente Araguas, Manuel Pereira e Fermín Bouza, que fora o seu mestre). Hai un a Augusto Acevedo, polo que nos conta o autor, poeta que foi neno da guerra; e outro a un tal Alberto, que segue algo así como un código de confidencias entre amigos.

Recolle tamén dous poemas dedicados aos seus fillos, Carmen e Mauro: «Dous nenos» e «Canción», esta última con aires de arrolo.

A quinta e derradeira parte, "gostaría de saber as veces...», compona un único e longo poema, «O Atlántico na beira para ti descoñecida», onde describe, probablemente a un americano, diversas cidades europeas e africanas.

\section{$2.5 \quad$ Farewell (2014)}

A —até agora- última obra de Yáñez é este poemario escrito inicialmente en castelán (e imos analizalo nesta lingua), aínda que publicado en edición bilingüe coa tradución para galego de cada poema nas páxinas pares. Conta cun limiar de Luis García Montero e ilustracións interiores de Raquel Fernández Sáez.

Consta de vinte e oito poemas divididos en dúas seccións: «Silencios»e «Rostros», máis un poema inicial e outro final. A maioría dos poemas teñen título; aos que non o teñen, farémoslles referencia polo seu primeiro verso.

Como xa apareceu en outros poemarios anteriores, o poema inicial, «el último abril de los noventa», trata de metapoesía, neste caso dos seus comezos como poeta. Do mesmo xeito, o poema final do libro, «Final», aborda o proceso de corrección e reescritura, unha vez rematada a obra, polo que resulta así a estrutura cíclica, circular, frecuente en Yáñez.

\footnotetext{
${ }^{5}$ Correspondencia persoal co autor.
} 
Non parece ter un tema ou fío condutor xeral claro na obra. Partindo de diversas lembranzas, son igualmente variados os motivos evocados, entre os que non hai ningún novo respecto á súa obra previa. En «Silencios» trata:

A súa nenez como punto de partida, como base do que é agora, en «De niño...», onde relembra ademais a seguridade que sentía entón fronte ao náufrago que pode ser agora de adulto.

Os elementos naturais, en «De la lluvia» e «Mientras el mar susurra», poemas moi sensitivos, nos que a choiva e o mar compren a súa función tópica inspiradora da poesía. Outro mar, neste caso de nubes, é atravesado durante unha viaxe en avión en «Venecia-Madrid», viaxe chea de sensacións na que a aterraxe supón unha volta á realidade cotiá sen posibilidade de voltar ao soño («Puerta solo de salida», di o penúltimo verso).

$\mathrm{O}$ amor é o asunto central en tres deles: «Day after tomorrow» é unha escena erótica nunha noite de desenfreo; «Recuerdas?», un desencontro amoroso; e «Quieto» trata da soidade ante o amor perdido.

Fai tamén un repaso a distintos artistas e personaxes, entre os que podemos supor que están os seus favoritos. En «Dos dalias, un crisantemo y tres gladiolos» asocia tres personaxes a cadansúas flores e sentimentos: o mimo Marcel Marceau son as dalias, a inxenuidade, o amargor. Lorca é o crisantemo, o visceral, o velenoso. Ariadna e o seu fío son os gladíolos, as lembranzas, a ausencia. En «7 acordes de jazz» describe a capacidade evocadora de John Scotfield respecto a diferentes escenas da súa vida, nun ambiente de aires románticos coa mención dos pintores Turner e Hölderling, e o músico Schubert.

En «Ruidos y silencios» enfronta o estudo da historia entre o tedioso academicismo e o apaixonante dos feitos en si mesmos e como foron vividos polos pobos, co exemplo da Revolución dos Caraveis en Portugal.

$\mathrm{O}$ tempus fugit, outra das constantes do autor, aparece en «A veces somos lo que no queremos» cun ton derrotista, de quen perdeu todas as ilusións. Esa sensación de langor aparece moi conseguida mediante o polisíndeto («y»), xunto coas imaxes dunha culleriña, un silencio cinematográfico ou os antigos vicios xa abandonados.

A segunda parte do poemario, «Rostros», pese ao seu título, non constitúe un conxunto de retratos. De feito, só aparecen propiamente dous: «Tu rostro III» e un autorretrato en «Mi rostro». Resulta curioso ademais como no primeiro emprega unha nomenclatura científica e no segundo céntrase no carácter da persoa, envolta en música de Mahler, compositor posromántico alemán.

O resto é outra miscelánea de temas: Un par deles van dedicados aos seus fillos («El rostro de Carmen» e «El rostro de Mauro»), e outros a familiares e coñecidos («El rostro de Irena», «Osório de Setúbal», «Rostro de Encarna»e «Glaucopis»). Outros dous son poemas urbanos: un de aire misantrópico a eses habitantes anónimos, «Sin rostros», e outro máis centrado na paisaxe urbana en «De tu rostro». 
Aspectos metapoéticos aparecen en «Tu rostro I», algo así coma os antitópicos do rostro de muller, con exaltación da beleza da sinxeleza fronte á sofisticación máis ridícula e manida dos beizos de coral e os dentes de perlas. «A Jaime Gil de Biedma» afronta tamén unha dicotomía entre poesía e realidade, cando intenta revivir sen éxito o que le nun poema do barcelonés visitando os lugares descritos por este.

Unha noite de borracheira (quizais para esquecer) e a posterior resaca son o tema de «Tu rostro II». E o realismo social, cunha moza que fai a rúa, aparece en «Rostro de mujer».

A peza final desta serie dá título ao poemario, «Farewell». Constitúe un longo repaso á súa vida, con certo sabor manriqueño (cambiando o río da vida por un tren en África), onde xoga co tempo, o existencialismo e incluso o surrealismo.

\section{SÍNTESE E CARACTERIZACIÓN FINAL DA SÚA OBRA}

Considerados os contidos e as formas da obra de Rafa Yáñez en conxunto, pódese encadrar dun xeito xeral nesa ampla e mal definida corrente que é a poesía posmoderna.

Temas como a metapoesía; a modernidade social despersonalizada das cidades fronte á modernidade estética capaz de extraer elementos poéticos daquela; a sexualidade e o erotismo, ás veces transgresivos; o exótico, decadente ou cosmopolita; o cinema, o expresionismo alemán, a música (case sempre clásica ou jazz); e o interese polo «eu» e o autobiografismo son, segundo Saldaña (2009: 161-210) e Álvarez Ramos (2011: 35), asuntos habituais desta poesía. E tamén na de Rafa Yáñez.

Recursos como a fragmentación dos textos (falta de puntuación, uso de puntos suspensivos ou tabulacións que dan sensación de estar ante un anaco máis que ante un texto completo), o eclecticismo, a hibridación de tendencias estéticas, con mestura dos tres grandes movementos da modernidade: romanticismo, simbolismo e vangardas históricas, caracterizan tamén o autor.

Nas formas destaca o abandono case absoluto do métrico e rítmico, sexa acentual ou por rima (Rodríguez-Gaona 2010: 64), non só mediante o verso libre, senón tamén co uso do prosaísmo (Saldaña 2009: 184), recurso este non moi frecuente en Yáñez. Con esta falta de métrica regular e de ritmo, o que a identifica como poesía son sen dúbida, ante todo, a linguaxe e as imaxes por este construídas; imaxes que derivan non de descricións fotográficas senón de sensacións: as xeradas por unha paisaxe, un rostro presente ou ausente, unha situación

Unha estrutura moi común nos seus poemas deriva da mestura do ficticio e o real, aínda que con límites netos; ao longo dunha composición é frecuente que desenvolva un soño, un sentimento, etc., que son truncados de súpeto nos últimos versos por unha volta á realidade, ao cotián.

Respecto á súa adscrición a unha corrente concreta dentro das actuais, resulta problemático, dada a cantidade de opcións literarias presentes e mestu- 
radas; así, como propón Saldaña (2009: 173-174), apenas podemos marcar algunhas tendencias. Se seguimos as revisadas por Villena (2010: 23-35) para a Generación de 2000, contemporánea con Yáñez en castelán, poderíamos falar dunha «poesía da experiencia», e sobre todo, curiosamente, nas súas primeiras obras. Dun maior «realismo crítico-radical»son as últimas, en especial en Axóuxeres da melancolía.

Outras correntes presentes, aínda que menos marcadas, son: a «metafísica» ou «irracionalista», coa proliferación de imaxes surrealistas e visuais nunha linguaxe confusa, pero non inintelixible; unha poesía «culturalista», chea de referentes intelectuais, non só poetas senón tamén pintores (especialmente románticos e impresionistas), músicos de jazz, actores...; o erotismo que mostra Yáñez non se achega ao «realismo sucio», e tampouco o fan as súas escasas imaxes escatolóxicas, que resultan máis ben cómicas.

Pola súa consideración como escritor de fronteira ou ectópico, temos que considerar o declarado polo propio autor ante as nosas preguntas.

Respecto ao bilingüísmo e o uso alternativo do galego e o castelán, di: «No sabría decirte diferencias. Para mí es un recurso literario».

Non hai interferencias entre as dúas linguas ao compor nunha ou outra. Non son frecuentes os castelanismos en galego, nin os galeguismos en castelán.

No feito de ter o galego como lingua principal de creación nun contorno castelán non parece existir ningunha militancia política, senón aspectos estéticos e sentimentais. De feito, aínda que nado en Galicia, non é fillo de galegos, senón de madrileño e salmantina:

Escogí el gallego porque me gusta, porque me resulta fácil escribir poemas y porque cuando vivía en Vilalba (Lugo) me socialicé en gallego (...). Para mí es una opción elegida libremente, me gusta la sonoridad y las posibilidades que ofrece.

Parece que non lle afecta a escasa repercusión de escribir en galego fóra de Galicia: «No sé si es condenarme al ostracismo». E insiste: «pero sí sé que es lo que me pide el poema. El lenguaje también es parte del mismo». En castelán ten, como vimos, o seu último poemario, aínda que nos anticipa: «tengo un proyecto que se titula Diálogos que está muy avanzado y va en la línea de lo social».

A literatura ectópica asóciase con frecuencia a uns temas e unhas formas peculiares, moitas veces independentemente dos lugares de orixe e destino dos autores. No caso de Rafa Yáñez, e seica extensible a outros membros do Grupo Bilbao, os temas máis propios da distancia á terra redúcense considerablemente respecto a outras épocas da literatura galega transterrada ou respecto a outros colectivos actuais:

O exilio e a situación política, asuntos que interesaron noutras épocas como o Franquismo ao Grupo Brais Pinto e aos exiliados en América, e aínda vixente en autores árabes de hoxe, por exemplo (Tresilian 2011), non existen no Madrid actual, cunha democracia asentada. 
Os problemas derivados da emigración, como a inadaptación ou o maltrato ao forasteiro, tampouco se respiran aquí como ocorría en Rosalía e os seus Cantares gallegos e segue ocorrendo noutras literaturas de fronteira onde os contrastes culturais son considerables —os árabes e os hispanos nos Estados Unidos-. A lingua non resulta tampouco motivo de queixa. Non hai unha defensa explícita do «galego» fronte a un posible centralismo castelán, agás no propio uso como lingua de creación, sen claras diferencias en canto a temas ou formas cando utiliza unha ou outra.

Porén, aparecen Galicia e a Terra Chá, coas súas paisaxes e os seus personaxes, como lembranzas da nenez. Non é tampouco unha ollada idealizada, senón melancólica, a unha etapa feliz da súa vida. Tampouco o ambiente rural galego presente en moitos poemas se enfronta ao ambiente urbano de outros; non idealiza nin demoniza ningún dos dous.

\section{CONCLUSIÓNS}

Coa análise da obra poética de Rafa Yáñez no seu contexto, é posible establecer a súa caracterización:

Como a dun poeta do seu tempo, acorde ás correntes e inquedanzas comúns de moitos poetas da súa xeración: os temas e as formas corresponden aos característicos da poesía posmoderna. Dentro desta, pódese falar máis ben dunha poesía da experiencia, aínda que con cada vez máis incursións noutros temas, sobre todo sociais.

Como poeta de fronteira, e coa súa vinculación ao $\mathrm{GB}$, desenvolve uns temas específicos, relacionados coa súa infancia na comarca luguesa da Terra Chá, e unha actividade editorial e de apoio entre escritores.

Esta situación de literatura transterrada en Yáñez e no GB constitúe un exemplo dun feito relativamente común que se dá ao longo da historia das letras galegas, e en xeral nas literaturas de países de emigración. Estas dan lugar, aínda que con matices en función das circunstancias específicas, ao tratamento dunha serie de temas máis ou menos constantes, que se poden resumir na hibridación: non esquecer as raíces culturais e, doutra, a incorporación ao contorno de acollida.

Os escritores galegos transterrados históricos, como Rosalía, Celso Emilio Ferreiro, Manuel Rivas... foron pezas determinantes para o desenvolvemento e renovación da súa literatura. Isto non foi así ata agora co Grupo Bilbao, aínda que sería desexable que os seus membros fosen pronto tidos en conta polo mundo académico e da crítica, máxime cando se atopan obras, como a de Rafa Yáñez, con calidades moi dignas.

\section{BIBLIOGRAFÍA}

Acuña, A. (2012) «Os primeiros anos do Grupo Bilbao (1996-2001)», RLL$C G V, 17$, pp. 261-272. 
Albaladejo, T. (2011) «Sobre la literatura ectópica». En: Adrian Bieniec, Szilvia Lengl, Sandrine Okou, Natalia Shchyhlebska (eds.), Rem tene, verba sequentur! Gelebte Interkulturalität. Festschrift zum 65. Geburtstag des Wissenschaftlers und Dichters Carmine/Gino Chiellino, Dresden, Thelem: 141-153

Álvarez Ramos, E. (2011) «La posmodernidad en la poesía contemporánea española: la búsqueda de los orígenes», Ogigia. Revista Electrónica de Estudios Hispánicos, 10, pp. 25-38.

Blanco, C. (2000) Introducción, en: Yáñez, R. Onte chovía, Madrid, ACEF, pp. 3-4.

Luna, L. (2010) «A colección O Roibén, vieiro de expresión poética do Grupo Bilbao», RLLCGV, XV, pp. 89-101.

Luna, L. (2012) La colección O Roibén, órgano de expresión poética del Grupo Bilbao, Tesis Doctoral, Universidad Nacional de Educación a Distancia, Inédita.

Mera, P. (2012) «Recensións», Madrygal, 15, pp. 292-293.

Rodríguez-Gaona, M. (2010) Mejorando lo presente. Poesía española última: posmodernidad, humanismo y redes, Madrid, Caballo de Troya.

Saldaña, A. (2009) No todo es superficie. Poesía española y posmodernidad, Valladolid, Universidad de Valladolid.

Tresilian, D. (2011) «Época de migración al norte. Escritores árabes en el extranjero», Culturas, 10, pp. 51-65.

Villena, L. A. (2010) La inteligencia y el hacha (un panorama de la generación poética de 2000), Madrid, Visor, pp. 7-36.

Yáñez, R. (2000) Onte chovía, Madrid, ACEF, Col. O Roibén.

Yáñez, R. (2001) Lembranzas e olvidos dun estraño. Madrid, ACEF. Col. O Roibén.

Yáñez, R. (2011) Da Chá ao lonxe, Instituto de Estudios Chairegos, Col. Biblioteca Chairega, Vilalba (Lugo).

Yáñez, R. (2013) Axóuxeres da melancolía, Ocaña, Lastura.

Yáñez, R. (2014a) Farewell, Madrid, Adeshoras.

Yáñez, R. (2014b) «Epílogo», Madrygal, 17, pp. 239-240. 
